\title{
RECENT DEVELOPMENT OF SLOVENE TOWNS - SOCIAL STRUCTURE AND TRANSFORMATION
}

\author{
Dejan Rebernik \\ Department of Geography, Faculty of Arts, University in Ljubljana, \\ Aškerčeva 2, 1000 Ljubljana, Slovenia \\ e-mail: dejan.rebernik@guest.arnes.si
}

\begin{abstract}
In Slovene towns and urban areas several processes of social transformation and change have been present in the last decade. As a consequence of political and economic transition increased social differentiation resulted in increased social segregation in urban areas. Some areas such as high-rise housing estates and part of older inner city areas were affected by social degradation and concentration of low-income population and ethnical minorities. In some parts of inner cities processes of reurbanisation and gentrification are taking place. However, the degree of social segragation is lower than in the cities of most transitional countries of Central and Eastern Europe.
\end{abstract}

Key words: social segregation, suburbanisation, gentrification, Slovene towns

\section{INTRODUCTION}

In Slovene towns and urban areas several processes of social transformation and change have been present in the last decade. As a consequence of political and economic transition increased social differentiation resulted in increased social segregation in urban areas. Some areas such as high-rise housing estates and part of older inner city areas were affected by social degradation and concentration of low-income population and ethnical minorities. However, the degree of social degradation is lower than in cities of most transitional countries of Central and Eastern Europe. Suburbanisation and loss of population in inner parts of urban areas, which started already in the seventies, remained intensive and caused the concentration of higher income groups of population in certain suburban areas. As a consequence of urban sprawl the highest increase of population was recorded in rural areas with good accessibility (Rebernik, 2003a). At the same time rural - urban migration continued and in some parts of inner cities, mostly in Ljubljana, processes of reurbanisation and gentrification were taking place. 


\section{ECONOMIC TRANSITION AND SOCIAL DIFFERENTIATION IN SLOVENIA}

Political and economic transition from one-party and planned economy to parliament democracy and market economy resulted, among other things, in increased social differentiation (Tamas, 2000). It was the case of all transitional countries of Central and Eastern Europe, but with important differences in degree and intensity of this phenomena. This is conditioned by many factors, such as general level of economic development and living standard, welfare system and its transformation in transition period, the importance of non-formal sector of economy etc.

In the group of transitional countries of Central and Eastern Europe Slovenia ranks among countries with moderate social differentiation. In $199813.6 \%$ of Slovene households were defined as poor, which is close to average value for the countries of European Union and less then in other transitional countries. Households whit above average degree of poverty are single older households and older couples, lone parent households, households with unemployed members and households with low education structure (Izvajanje strategije...,2002).

Recent research has shown that income inequality has increased considerably in the first years of transition period, but has decreased again after 1993. In the first years of transition income inequality increased mostly as a consequence of increased differences in salaries and increased unemployment. After 1993 income inequality decreased again as a result of much higher degree of »social transfers « such as unemployment subsidies, social grants and pensions in the structure of incomes of poor households. In poor households social welfare incomes represented only $8 \%$ of all incomes in 1983, $16 \%$ in 1993 and 21 $\%$ in 1998. In this way the welfare subsidies helped to lower general social differentiation. But on the other hand this resulted in dependency of a large part of population on welfare system. One of the consequences of such development is increased social exclusion and segregation (Izvajanje strategije...2002).

\section{SOCIAL STRUCTURE OF SLOVENE TOWNS IN SOCIALIST PERIOD}

It has to be pointed out that the population was socially stratified in the former socioeconomic system as well. Although income disparities were limited, they were by no means insignificant. A number of researches carried out by Slovene geographers showed that social segregation and distinct social areas were present in Slovene towns in the socialist period (Rebernik, 2002).

Social structure of Slovene towns at the beginning of the nineties was characterised mainly by the differences in the socio-economic status of the population. There were considerable disparities between urban areas with high socio-economic status and those with low socio-economic status. Low income and non-Slovene population concentrated in socially deprived areas such as neighbourhoods of illegally constructed single-family houses 
on the periphery of urban areas as well as in parts of the old city center, older suburbs and some high rise housing estates. On the other hand in the areas with good living conditions and a high standard of housing formed social areas with high socio-economic status of population. These were primarily central parts of cities and towns with good housing and newer neighbourhoods of single-family houses.

But relatively average and heterogeneous socio-economic structure of the population was characteristic of a large part of urban areas. This is a result of a specific urban development and low social stratification of the population in the former socialist socio-economic system. The housing market and spatial mobility of the population within the city were limited until 1990, thus slowing down the social segregation. Spatial social differentiation was, within the framework of the values of the socialist system, considered negative and unacceptable, what was also taken into account in the housing policy and the town planning. Public housing, mostly in the form of high-rise housing estates represented more than $70 \%$ of all housing construction in urban areas. Public housing was primarily funded by the contributions made by both employees and state-owned enterprises. A certain quantity of flats was sold, but most were allocated to lower and middle-income households, which resulted in very heterogeneous socio-economic structure of the population in high-rise housing estates (Rebernik, 2003b).

\section{RECENT PROCESSES OF SOCIAL TRANSFORMATION IN SLOVENE TOWNS}

In the last decade the social structure of Slovene towns is undergoing considerable change. As a part of general social transformation in transitional period, the most important process is an increased social segregation of population. It is conditioned by an increased general social differentiation, development of housing market, privatisation of housing and increased interurban mobility of population.

Up to 1990 residential mobility in Slovene urban areas was very low (ك̌ses, 1998). This was conditioned by low degree of private ownership and underdeveloped housing market, but also by social and psychological factors. Recent research showed an increased residential mobility after 1991 . This can be attributed mainly to the development of housing market due to privatisation of public housing sector. Residential mobility is particularly high in high-rise housing estates, where more than $25 \%$ of inhabitants moved in in the last 10 years (Rebernik, 2002).

After 1990, and after 1995 in particular, market-housing construction rapidly gained ground. Due to considerable demand and relatively high prices of housing, private capital invested in housing construction yields significant profit. As extensive areas of developed land are scarce, housing construction is spatially spread in the form of small residential areas. Some major complexes of new buildings were constructed in certain former Industrial or military areas. New housing is relatively expensive, often located on attractive sites in inner city areas, and attracts mostly higher income social groups. 
In addition, older residential districts with good accessibility and favourable living conditions are still attractive for the population with above-average incomes. It is the case of former elite parts of towns, like villa neighbourhoods and upper class apartment buildings in inner city areas. Another example are neighbourhoods of one-family houses, built mostly after 1970 .

Main goal of privatisation of housing was to reduce the share of public housing and to provide funds for a new cycle of public housing construction (Stanovnik, 1995). After privatisation the share of public housing dropped from $33 \%$ to $12 \%$. In urban areas the privatisation was even more pronounced. In Ljubljana public housing sector was reduced from $42 \%$ to $10 \%$ (Mandič, 1995). Because of very convenient price, which reached only about $10 \%$ of market price, purchase was also made by the strata of the population which now only hardly meets the obligations arising from property held, e.g. maintenance of a flat or a house. Therefore, Slovenia now faces the problem of "poor owners" (Mandič, 1995). This situation may result in improper maintenance and, as a consequence, in degradation of the housing stock in the areas with low socio-economic status of the population, mainly in certain high-rise housing estates. This may further lead to rapid social degradation of such areas.

High-rise housing estates, which represent most wide spread form of residential areas in Slovene towns, are thus involved in a process of social and physical degradation, as is the case in other countries of Eastern and Central Europe. Particularly in older and larger housing estates characteristics of social degradation can be observed, e.g. concentration of lower income groups, older households and ethnical minorities. But the degree and intensity of social and physical degradation is in general much less pronounced then in other transitional countries. We definitely cannot speak about strong concentration of poor and marginal social groups, much higher crime rates than in the rest of residential areas, decreasing real estate prices, out-migration of middle class households and vacant flats. For this there are several reasons. Contrary to most of former Eastern block countries, in Slovenia high-rise housing estates were relatively small, accessible, well connected and integrated with the rest of urban space. Quality of life in high-rise housing estates is in general good and in certain elements even better than in some other residential areas (Rebernik, 2003b).

The areas with the lowest socio-economic status of population are the illegally constructed neighbourhoods of single-family houses on the periphery of urban areas. They are typical for all larger cities and towns in Slovenia. These neighbourhoods are characterized by a concentration of low income population, a predominance of non-Slovene residents, a very low housing standard, and poor living conditions. They developed between the seventies and the end of eighties, in the period of most intensive migration from rural parts of Yugoslavia. In the last five years, after a period of stagnation, we can observe the development of new neighbourhoods of this type in larger Slovene urban areas. But because of their convenient location and the general shortage of building grounds some of these areas are also attracting new housing construction, causing their social transformation. 
Another new phenomena in Slovene towns are reurbanisation and gentrification of certain older inner city areas. It is mostly the case of Ljubljana, in smaller extent also of Maribor and other larger towns. Parts of old medieval centers, older working - class neighbourhoods and industrial areas are thus being renovated or replaced by new housing. Only small areas are included in this process. New or renovated housing is attracting highincome population, which is in sharp contrast with predominantly lower social structure in these areas.

Suburbanisation and loss of population in inner parts of urban areas, which started already in the seventies, remains intensive (Ravbar, 1997). One of the consequences of these phenomena is the concentration of middle and higher income groups and younger population in certain suburban areas. Due to lack of building grounds and high real estate prices in urban areas the highest increase of population in the last decade was recorded in rural areas around larger cities and towns with good accessibility. In the last three decades areas of suburbanisation around Slovene towns widened to locations up to 30 or even 40 kilometres from the center of urban region. This phenomenon, which can be best described as urban sprawl, is however limited to lager urban regions and is most pronounced around Ljubljana. As an example, many former settlements of second homes around Ljubljana are being transformed into residential areas.

We can conclude with a general observation that Slovene cities and towns are experiencing processes of social change and transformation similar to urban areas in other transitional countries. These processes are however specific for Slovenia and in general less intense then in most other transitional countries of Central and Eastern Europe.

\section{References}

Egedy, Tamas., 2000: The Situation of High-rise Housing Estates in Hungary. Humgary Towards $21^{\text {st }}$ Century, Hungarian Academy of Sciences, Budapest.

http://www.sigov.si/zmar/arhiv/izbor/4ucinki/sociucin/eub0397.html

Izvajanje strategije socialnega vključevanja s poročilom o uresničevanju programa boja proti revščini in socialni izključenosti. Ministrstvo za delo, družino in socialne zadeve, 2002, www.sigov.si/mddsz/pdf/revscina.pdf

Mandič, S., 1995: Stanovanje, družina in otrok: nekaj problemov v tranzicijskem obdobju, Urbani izziv 28, 29, Urbanistični inštitut, Ljubljana

Ravbar, M., 1997: Slovene Cities and Suburbs in Transformation, Geografski zbornik XXXVII, Ljubljana, Science Research Center of the Slovenian Academy of Sciences and Arts Geographica Institute, $65-110$.

Rebernik D., 2002: Social structure and transformation of Ljubljana (Socialnogeografska zgradba in preobrazba Ljubljane), Geografija Ljubljane, Ljubljana, Oddelek za geografijo Filozofske fakultete Univerze v Ljubljani, 83 - 114.

Rebernik D., 2003a: Ljubljana urban region - Development Trends, Problems and Possibilities, Dela 19, Department of Geography, faculty of Arts, University of Ljubljana, $165-176$. 
Rebernik, D., 2002: Urban Geography of High Rise Housing Estates and Its Application in Urban Planning (Urbano-geografsko proučevanje blokovskih stanovanjskih sosesk kot element urbanističnega planiranja), Dela 18, Department of Geography, faculty of Arts, University of Ljubljana, $463-476$.

Rebernik, D., 2003b: Development and transformation of high-rise housing estates in Ljubljana, Rhein-mainische Forschungen, 124, Die Zukunft der Staete, 93 - 104

Špes, M., 1998: Degradation of Environment as an Element of Diferentiation of Urban Landscape (Degradacija okolja kot element diferenciacije urbane pokrajine). Geographica Slovenica, 30 . 